\title{
Quality characteristics and plasmin activity of thermosonicated skim milk and cream
}

\author{
S. Vijayakumar, ${ }^{*}$ D. Grewell, † C. Annandarajah, $†$ L. Benner, $\ddagger$ and S. Clark $\ddagger^{1}$ \\ *Promotion In Motion Inc., Allendale, NJ 07401 \\ †Department of Agricultural and Biosystems Engineering, and \\ $\ddagger$ Department of Food Science and Human Nutrition, lowa State University, Ames 50010
}

\begin{abstract}
The shelf life of pasteurized milk is limited by heatstable proteases, which cause gelation and bitter taste upon extended storage of milk. Ultra-high temperature processing inactivates proteases but detrimentally affects milk's sensory quality. An adjunct to pasteurization is desired to extend milk's shelf life while maintaining quality characteristics. In this study, the effects of combined heat and ultrasound (thermosonication) on total plasmin activity and various quality characteristics of skim milk and cream were studied. Thermosonication, at an average power of $115 \mathrm{~W}\left(152 \mu \mathrm{m}_{\mathrm{p}-\mathrm{p}}\right.$, where $\mathrm{p}-\mathrm{p}=$ peak-to-peak amplitude) for $3 \mathrm{~min}$, decreased the total plasmin activity (i.e., plasmin- and plasminogenderived activity) by nearly $94 \%$ in fresh skim milk and cream. Enzyme activity in thermosonicated skim milk samples measured at the end of $30 \mathrm{~d}$ was 5 - to 10 -fold higher than on d 0, but remained stable in thermosonicated cream. Descriptive analysis of odor attributes was conducted for up to 4 wk with 8 trained panelists. No significant differences were observed between the intensities of offensive "eggy" and "rubbery" odor attributes of thermosonicated skim milk and pasteurized commercial skim milk and cream. In addition, lightness $\left(\mathrm{L}^{*}\right)$ values and viscosity were not adversely affected by thermosonication. Thermosonication decreased the fat globule size in skim milk and cream, and the homogenizing effect increased with treatment time. Thermosonication at average powers of $104 \mathrm{~W}\left(133 \mu \mathrm{m}_{\mathrm{p}-\mathrm{p}}\right)$ and $115 \mathrm{~W}\left(152 \mu \mathrm{m}_{\mathrm{p}-\mathrm{p}}\right)$ for 1 and $3 \mathrm{~min}$ destroyed coliforms and over $99 \%$ of the total aerobic bacteria. The total aerobic bacteria counts of thermosonicated skim milk and cream samples were less than $20,000 \mathrm{cfu} / \mathrm{mL}$ on d 30. Because thermosonication did not induce off-aromas or viscosity changes but did inactivate microorganisms and protease enzymes, thermosonication may be an
\end{abstract}

Received February 5, 2015.

Accepted June 13, 2015.

${ }^{1}$ Corresponding author: milkmade@iastate.edu appropriate adjunct to pasteurization to extend milk shelf life.

Key words: bacteria, sensory, shelf life, ultrasound

\section{INTRODUCTION}

Milk is a highly perishable product but it competes in a market rich with beverages that have a long shelf life, such as bottled water, fruit juice, soda, and sports beverages. Milk processors and dairy scientists seek methods to improve the shelf life of fluid milk to improve competitiveness. The shelf life of milk depends on various factors, such as the quality of incoming raw milk, processing time and temperature, survival of spoilage microorganisms, storage temperature, exposure to light, and postprocessing contamination (Bylund, 1995; Simon and Hansen, 2001). Conventional pasteurization [i.e., HTST continuous pasteurization and low-temperature, long-time (LTLT) batch pasteurization] destroys all pathogens and many spoilage microorganisms, rendering milk a shelf life of approximately 14 to $21 \mathrm{~d}$ when bottled and stored under refrigerated conditions (Allen and Joseph, 1985; Boor, 2001). Ultrahigh temperature processing, where the milk is heated to $138^{\circ} \mathrm{C}$ and held there for at least 2 s (FDA, 2009), can extend milk's shelf life to at least $60 \mathrm{~d}$ at room temperature (Boor and Nakimbugwe, 1998). However, extreme heating of milk can lead to Maillard or caramelization reactions (Clare et al., 2005) and an increase in sulfur compounds and off-flavors (Christensen and Reineccius, 1992). Chapman et al. (2001) showed that children aged 6 to 11 found $2 \%$ UHT milk to be undesirable. Thus it is important that any proposed treatment does not compromise the sensory quality and nutritional properties of milk.

When milk is pasteurized, spores of thermoduric microorganisms, as well as some native and microbial enzymes, survive the heat treatment and can cause spoilage under extended storage. Proteases are one of the major types of enzymes that limit the shelf life of fluid milk (Fox and Kelly, 2006). Proteases can be indigenous or produced by microorganisms that survive 
milk pasteurization or postpasteurization contaminants, such as Pseudomonas spp. or Bacillus spp. (Sorhaug and Stepaniak, 1997). Proteases can have either beneficial or detrimental effects on the flavor and texture of dairy products (Ismail and Nielsen, 2010). However, in fluid milk, proteases that hydrolyze milk proteins into bitter peptides or lead to flocculation or gelation are particularly troublesome.

Plasmin, a fibrinolysin secreted into the milk from blood plasma through the mammary cells, is the major indigenous protease found in milk (Bastian and Brown, 1996; Fox and Kelly, 2006; Kelly et al., 2006). The activity of the plasmin system, consisting of plasmin (PL), plasminogen (PG), plasminogen activators (PA), plasminogen activator inhibitors, and plasmin inhibitors, depends greatly upon the processing and storage conditions of milk (Ismail and Nielsen, 2010). Although inhibitors are soluble in the milk serum, the rest of the plasmin system (i.e., PL, PG, and PA) is associated with casein micelles (Bastian and Brown, 1996; Fox and Kelly, 2006). Upon storage, PG is cleaved at the $\mathrm{Arg}^{557}$ $\mathrm{Ile}^{558}$ peptide bond by proteases such as urokinase and tissue-type PA (Bastian and Brown, 1996; Fox and Kelly, 2006). This proteolytic cleavage converts inactive PG into active PL, resulting in higher PL activity (Fox and Kelly, 2006). Furthermore, the plasminogen activator inhibitors are inactivated by commercial thermal pasteurization, whereas PL is stable to pasteurization (Fox et al., 2003). Thus, PL and PG survive pasteurization and are somewhat resistant to HTST and UHT treatments (Newstead et al., 2006; Ismail and Nielsen, 2010). Alichanidis et al. (1986) reported that at least $30 \%$ of the porcine plasmin activity remained in skim milk that was subject to UHT treatment $\left(143^{\circ} \mathrm{C}\right)$ and that the $\mathrm{D}$-value (time required for $90 \%$ reduction in activity) in skim milk at $143^{\circ} \mathrm{C}$ was approximately $10 \mathrm{~s}$.

Emerging technologies such as high-pressure processing (García-Risco et al., 2003; Borda et al., 2004; Bilbao-Sainz et al., 2009), pulsed electric field (Bendicho et al., 2005), and ultrasound (Vercet et al., 2002) have been explored to investigate their potential to inactivate shelf life-limiting enzymes in milk, particularly proteases. Ultrasound is a form of energy generated by cyclic sound pressure waves of frequencies that are greater than the upper limit of human hearing range, typically above 18 to $20 \mathrm{kHz}$ (Patist and Bates, 2008). High-power ultrasound is typically produced at lower frequencies (ranging from 16 to $100 \mathrm{kHz}$ ) and thus is typically used for emulsion generation and cell disruption where cavitation is the dominant effect and free radical generation ("sonochemistry") is limited. When ultrasound waves are passed through a liquid food material, alternating regions of high and low pres- sures (i.e., compression and expansion, respectively) are created, which induce cavitation and form gas or vapor bubbles (Nguyen and Anema, 2010; Pingret et al., 2012). These gas bubbles expand because of increased gas diffusion during the expansion cycle and rapidly condense (implode) when the bubbles reach an unstable size. The condensed bubbles collide violently, resulting in shock waves (mechanical or shear forces)-regions of high temperature and pressure. The streaming increases heat and mass transfer in the milk (Jayasooriya et al., 2004; Zheng and Sun, 2006), resulting in spatially confined high temperatures and pressures; the average bulk temperature increases only moderately compared with the temperature in a collapsing bubble (Nguyen and Anema, 2010). Cavitation results in a localized pasteurization effect without causing a significant increase in macro-temperature (Tiwari et al., 2009) but because of streaming, the bulk milk is treated. In addition to cavitation, the shearing effect between the sonication horn and milk also produces heat (Pingret et al., 2012). Destruction of microorganisms or inactivation of enzymes can be induced by one or more of these consequences of sonication. However, the cavitation created depends on many factors, such as frequency and intensity of ultrasound waves, ambient temperature and pressure, and product properties such as viscosity, surface tension, vapor pressure, among others.

Although not yet widely used in the dairy industry, ultrasound has a broad range of applications, including but not limited to cleaning (Kivelä, 1996); promoting nucleation and reduction of ice crystal size in ice cream (Zheng and Sun, 2006); reducing the size of fat globules and creating emulsions (Villamiel and de Jong, 2000b); increasing water-holding capacity and viscosity and reducing syneresis in yogurt (Wu et al., 2001); reducing viscosity and controlling the rate of age thickening of concentrated skim milk (Zisu et al., 2013); and decreasing the fermentation time of yogurt (Wu et al., 2001). Wu et al. (2001) showed that high-power ultrasound $(450 \mathrm{~W})$ is capable of homogenizing fluid milk better than commercial homogenization. Villamiel and de Jong (2000b) demonstrated that ultrasonication at higher temperatures (between $70^{\circ}$ and $75^{\circ} \mathrm{C}$ ) resulted in a more homogeneous particle distribution than heat or sonication alone.

High-power ultrasound has also proven to be useful in inactivating microorganisms (Wrigley and Lorca, 1992; Villamiel and de Jong, 2000a; Cameron et al., 2008, 2009), suggesting good potential for extension of fluid milk shelf life. However, ultrasound has only been effective in enzyme inactivation when combined with other factors, such as heat or pressure (Villamiel 
and de Jong, 2000b; Chouliara et al., 2010). Protease produced by Pseudomonas fluorescens was resistant to manothermosonication (ultrasound combined with heat and pressure) at $30^{\circ} \mathrm{C}$ but was very sensitive at $76^{\circ} \mathrm{C}$ (Vercet et al., 2002). Manas et al. (2006) reported that ultrasonication $(117 \mu \mathrm{m})$ at room temperature and atmospheric pressure had no effect on lysozyme activity, whereas applying $200 \mathrm{kPa}$ pressure and increasing temperature to between 60 and $80^{\circ} \mathrm{C}$ increased the inactivation rate; the power value was not reported. A synergistic effect is observed when heat is combined with ultrasound (Lopez et al., 1994; Villamiel and de Jong, 2000b; Vercet et al., 2002), and this opens the door for many applications in the food industry, particularly in enzyme inactivation.

Although ultrasound has great potential for application in the dairy industry, the technique is not currently used for processing or preservation purposes because of the limited knowledge of the effects upon shelf-limiting enzymes, sensory and other quality parameters, energy consumption, and scale-up potential. A few reports (Villamiel and de Jong, 2000a,b; Cameron et al., 2008, 2009; Chouliara et al., 2010; Khanal et al., 2014) have provided insight into the promise of thermosonication (Ts) for microbiological, chemical, and sensory quality of skim milk or full-fat milk, but most utilized previously pasteurized milk or conducted treatments in ice baths, and analyses were limited to milk stored for less than 1 wk. The present work was designed to evaluate skim milk and cream quality for $30 \mathrm{~d}$. The objective was to investigate the combined effect of heat and ultrasound (i.e., Ts) on the total plasmin activity, odor profile, lightness value, viscosity, fat globule size, and microflora to consider the potential of Ts for extending milk shelf life.

\section{MATERIALS AND METHODS}

\section{Procurement}

Fresh raw whole milk $(3.60 \pm 0.20 \%$ fat $)$ was procured from the bulk tank of Iowa State University's dairy farm (Ames, IA). Raw whole milk was stored at 4 $\pm 1^{\circ} \mathrm{C}$ immediately after collection and separated into skim milk $(0.53 \pm 0.12 \%$ fat $)$ and cream $(45.50 \pm 2.18 \%$ fat) within $1 \mathrm{~h}$ of procurement. A centrifugal cream separator (1,750 rpm; Varidrive Motor, US Electrical Motors Inc., Milford, CT) from the Center for Crops Utilization Research pilot plant of Iowa State University was used for separation. All samples were treated by Ts, heating, or both within 4 to $8 \mathrm{~h}$ of separation and stored at $4 \pm 1^{\circ} \mathrm{C}$.

Bovine plasmin, EDTA, and $\mathrm{NaOH}$ were purchased from Fisher Scientific (Fair Lawn, NJ). Trizma buffer
(pH 7.4), NaCl, H-D-valyl-L-leucyl-L-lysine- $p$-nitroanilide dihydrochloride (VALY, V7127), $\varepsilon$-amino caproic acid (EACA), urokinase, plate count agar medium, and violet red bile agar medium were procured from Sigma-Aldrich (St. Louis, MO). Thinwall, Ultra-Clear ultracentrifuge tubes $(14 \times 95 \mathrm{~mm})$ were purchased from Beckman Coulter (Brea, CA).

\section{Treatments}

Approximately $100 \mathrm{~mL}$ of milk was heated to $65^{\circ} \mathrm{C}$ before sonication. Thermosonication was completed using a batch sonicator (Branson Ultrasonics 2000 series, Danbury, CT), with a maximum output power of 2.2 $\mathrm{kW}$. Ultrasound was generated at $20 \mathrm{kHz}$ frequency; a 1:1 booster and a 1:8 sonicating horn were used. The sonication vessel used was a glass rosette cooling cell with water jacket from Thomas Scientific (9655U20; Swedesboro, NJ). The glass chamber features loops at the bottom that allow for circulation of liquid. The sonicating horn was clamped and inserted into the sample with the tip of the horn approximately at the center of the chamber. Average powers of $77\left(107 \mu \mathrm{m}_{\mathrm{p}-\mathrm{p}}\right.$, where $\mathrm{p}-\mathrm{p}=$ peak-to-peak amplitude), $104\left(133 \mu \mathrm{m}_{\mathrm{p}-\mathrm{p}}\right)$ and $115 \mathrm{~W}\left(152 \mu \mathrm{m}_{\mathrm{p}-\mathrm{p}}\right)$ were used for sonication time of 1 and $3 \mathrm{~min}$. Sonication was conducted in 30-s intervals, with a 1-s break (i.e., two 30-s intervals for a sonication time of $1 \mathrm{~min}$ and six 30-s intervals for a sonication time of $3 \mathrm{~min})$ to prevent the sample from overheating. Preliminary Ts experiments [104 W $\left(133 \mu \mathrm{m}_{\mathrm{p}-\mathrm{p}}\right)$ for $2.5 \mathrm{~min}]$ conducted on commercially pasteurized skim, reduced-fat, and whole milk samples (data not shown) resulted in an increase of undesirable burnt/plastic/ rubbery aroma (evaluated by 2 expert dairy judging panelists, with over $30 \mathrm{~h}$ of training in the evaluation of milk quality). Thus, a maximum of 3 min was selected to prevent any damages to the quality of fresh skim milk and cream even though the system can be operated in continuous mode. Because of the importance of temperature control (Nguyen and Anema, 2010), a circulating water bath was connected to the entrance and exit ports of the sonication vessel using rubber tubing. Water at $72 \pm 0.5^{\circ} \mathrm{C}$ was circulated through the jacketed Pyrex glass sonication vessel during sonication to ensure that the sample temperature was taken up to $72^{\circ} \mathrm{C}$ and held there or slightly above (due to sonication) for at least $15 \mathrm{~s}$ (to mimic HTST pasteurization). Controlling the temperature during sonication is important because temperatures above those used for commercial pasteurization can affect the sensory properties of milk and cause whey protein denaturation. Trials were conducted to ensure that milk temperature did not decrease below $60^{\circ} \mathrm{C}$ before the start of sonication or increase above $75^{\circ} \mathrm{C}$ during the sonication process. 
In addition to raw and thermosonicated samples, skim milk and cream samples that were heated to $72^{\circ} \mathrm{C}$ for $1 \mathrm{~min}$ and $3 \mathrm{~min}$ were also analyzed (heated controls). All treatments were applied in random order and in duplicate. Samples for odor evaluation were stored in Nalgene bottles and stored at $4 \pm 1^{\circ} \mathrm{C}$ (laboratory refrigerator). For sensory evaluation, triplicate treatments of Ts at $115 \mathrm{~W}\left(152 \mu \mathrm{m}_{\mathrm{p}-\mathrm{p}}\right)$ for 3 min were prepared and evaluated in addition to store-bought pasteurized skim milk and cream samples as unheated controls.

\section{Total Plasmin Assay}

Total PL activity is defined as the activity of PL determined after the conversion of inactive PG to active PL in the milk or cream samples; Korycka-Dahl et al. (1983) reported that incubating milk with $50 \mathrm{mM}$ EACA for $2 \mathrm{~h}$ resulted in $80 \%$ recovery of the enzyme activity in serum. Total native PL activities in skim milk and cream samples were determined using the conventional methodology described by Politis et al. (1993), which measures PL and PG activity in both the serum (whey) and casein fractions. This (Korycka-Dahl et al., 1983) is a modified version of the original method developed by Rollema et al. (1983). Approximately 5 $\mathrm{mL}$ of the sample was incubated with an equal volume of $50 \mathrm{~m} M$ EACA for $2 \mathrm{~h}$ at room temperature. This allows the dissociation of the PL and PG from the casein micelles and their transfer into the milk serum fractions. The treated sample was then ultracentrifuged using a Beckman L8-M Ultracentrifuge (Indianapolis, IN) at $100,000 \times g$ for $1 \mathrm{~h}$ at $4^{\circ} \mathrm{C}$ to separate the milk serum and casein fractions. The top cream layer was discarded and the serum fraction was separated by decanting. The casein pellets were reconstituted to their original volume in $50 \mathrm{~m} M$ Trizma buffer containing $110 \mathrm{mM}$ $\mathrm{NaCl}$, at room temperature $\left(\sim 21^{\circ} \mathrm{C}\right)$. Approximately 50 $\mu \mathrm{L}$ of the milk serum or reconstituted casein was mixed with $950 \mu \mathrm{L}$ of $50 \mathrm{~m} M$ Trizma buffer containing 110 $\mathrm{m} M \mathrm{NaCl}, 0.6 \mathrm{~m} M \mathrm{~V} 7127$, and $2.5 \mathrm{~m} M \mathrm{EACA}$, at room temperature $\left(\sim 21^{\circ} \mathrm{C}\right)$. To this mixture, 150 plough units of urokinase was added, which started converting the inactive $\mathrm{PG}$ to active $\mathrm{PL}$ in the mixture. The reaction mixture was incubated at $37^{\circ} \mathrm{C}$ for $1 \mathrm{~h}$ to allow sufficient conversion of the PG (Korycka-Dahl et al., 1983). The absorbance of the reaction mixtures was read at $405 \mathrm{~nm}$ at 60 -min intervals (through Fisherbrand UV methacrylate cuvettes; Fisher Scientific, Fair Lawn, $\mathrm{NJ}$ ) of $10-\mathrm{mm}$ path length and $1.5-\mathrm{mL}$ capacity), and absorbance versus time curves were plotted. The rate of $p$-nitroanilide formation was calculated from the increasing linear portion of the curve. A similar reaction mixture without the milk serum or reconstituted casein fraction served as the blank. Enzyme activity was calculated from a standard curve, prepared using known concentrations of bovine PL. One unit of activity of PL plus PG was defined as the amount of the enzyme that produced a change in absorbance at $405 \mathrm{~nm}$ of 0.001 in 1 min when $p$-nitroanilide was measured in the reaction mixture (Korycka-Dahl et al., 1983). Percentages of total PL activity of the heated and sonicated skim milk and cream samples were calculated based on the total PL activity of the initial raw skim milk and cream sample.

\section{Lightness}

For an evaluation of potential color change, the lightness or reflectance $\left(\mathbf{L}^{*} ; 0=\right.$ black; $100=$ white $)$ value of the thermosonicated skim and heavy cream samples were measured with a LabScan XE spectrophotometer (HunterLab, Reston, VA) on d 1, 15, and 30. Approximately $20 \mathrm{~mL}$ of the fluid sample was poured into a transparent glass circular dish. The colorimeter was calibrated against white and black tile standards, and operated at a $10^{\circ}$ angle of illuminant D65. All samples were tempered to $23 \pm 1^{\circ} \mathrm{C}$ before analysis. The glass dish was rinsed with deionized water and wiped dry between samples.

\section{Viscosity}

Viscosity of the samples was determined using a Haake RS150 Rheometer (Thermo Scientific, Waltham, MA). A double gap cylinder and DG41 sensor were used. Air pressure was maintained between 250,000 and 300,000 $\mathrm{Pa}$, and shear rates of 0 to $1,000 \mathrm{~s}^{-1}$ were used. Samples were tempered to $23 \pm 1^{\circ} \mathrm{C}$ before analysis. The sensor was fixed to the rotor and zeroed with the cylinder. Approximately $6.3 \mathrm{~mL}$ of the sample was pipetted into the coaxial cylinder. The sensor was then taken to the default gap of $5.1 \mathrm{~mm}$ before it was allowed to start the rheological measurements. Rheological responses of the samples were modeled using the Haake Rheowin Data Manager provided by Thermo Scientific to determine the viscosity of the sample, and the Newton law model was used to fit the flow behavior of the milk samples, because milk is a Newtonian fluid.

\section{Milk Fat Globule Size}

Sizes of fat globules in raw and treated milk and cream samples were determined using a Mastersizer 2000 particle size analyzer (Malvern Instruments, Malvern, UK). The system is based on a laser light scattering technique. The laser obscuration rate was 
maintained between 13.2 and $18.0 \%$ and the pump/ stir speed was set at 2,040 rpm. The sample beaker was filled with deionized water for flushing the tank thrice and for laser alignment. Deionized water was also used as the sample dispersant. The refractive indices of milk fat and deionized water are 1.45 and 1.33 , respectively. Milk and cream samples were diluted in the ratio of 1:1 using $35 \mathrm{~m} M$ EDTA (pH adjusted to 7.0 using $\mathrm{NaOH}$ ), which chelates calcium and facilitates dissociation of the casein micelles, thus removing the casein micelles from the fat globule membranes. The diluted sample was then dispersed into sample beaker filled with the dispersant for measurement. The diameter of the distribution peak, Sauter diameter $\left(\mathbf{D}_{3,2}\right)$, and the volume-weighted diameter $\left(\mathbf{D}_{4,3}\right)$ were determined by the Malvern software. The specific area $(\mathrm{S})$ was calculated from the Sauter diameter $\left[S=6 /\left(\rho \times D_{3,2}\right)\right]$, where $\rho$ is the density of milk fat, which is 0.92 (Mulder and Walstra, 1974).

\section{Microbial Analysis}

Microbiological quality of milk and cream samples was evaluated by enumerating total aerobic count (TAC) and coliform count. Raw samples were analyzed only on d 1 (within $24 \mathrm{~h}$ of d 1), whereas heated and thermosonicated samples were analyzed on $\mathrm{d} 1 \pm 24$ $\mathrm{h}, \mathrm{d}$ 15, and d 30. Plate count agar (Sigma-Aldrich) medium was used to enumerate TAC. Medium was dissolved in deionized water using a magnetic stirrer on a hot plate heater, boiled for $1 \mathrm{~min}$, autoclaved at $121^{\circ} \mathrm{C}$ and $100 \mathrm{kPa}$ for $15 \mathrm{~min}$, and cooled to $45 \pm 5^{\circ} \mathrm{C}$ before plating. Samples were diluted in $0.1 \%$ sterile peptone solution (Sigma-Aldrich) and plated using the pourplating method. During plating, an overlay method was used to reduce the spreading of the colonies. Plates were incubated at $37^{\circ} \mathrm{C}$ and colonies were enumerated after $48 \mathrm{~h}$ (Marshall, 1992). Total aerobic count was expressed as colony-forming units (cfu) per mL. Violet red bile agar medium was used to enumerate coliforms. Medium was dissolved in deionized water on hot plate, boiled for $1 \mathrm{~min}$, and cooled to $45 \pm 5^{\circ} \mathrm{C}$. Samples were diluted in $0.1 \%$ sterile peptone solution and plated using the pour-plating method. Plates were incubated at $37^{\circ} \mathrm{C}$ and colonies were enumerated after $24 \mathrm{~h}$. Coliform count was expressed as colony-forming units per milliliter (Marshall, 1992).

\section{Descriptive Analysis}

Descriptive sensory analysis of odor attributes of thermosonicated skim milk and cream was conducted; flavor analysis was not conducted because the milk was not legally pasteurized. Approval for use of human subjects was obtained from the Institutional Review Board of Iowa State University. Eight students or employees of Iowa State University were recruited to serve as panelists. The participants were required to drink milk at least once a month, have no aversions to odor associated with dairy products, and to have interest in sensory evaluation. None were excluded based on sex, nationality, ethnicity, or smoking. Ten 1-h training sessions were conducted over a period of $5 \mathrm{wk}$. During the first week, samples of pasteurized skim milk, whole milk, and heavy whipping cream (Anderson Erickson Dairy Inc., Des Moines, IA) obtained from the local grocery store were used to familiarize panelists with the odors associated with fluid milk and cream. At the end of the first session, the odor detection ability of the panelists was evaluated using a triangle test and no panelists were excluded. During the second session, terminology for odor attributes were developed using samples of heated and thermosonicated (preheated to $60^{\circ} \mathrm{C}$ and sonicated at average powers of $77 \mathrm{~W}$ for $1 \mathrm{~min}$ and $115 \mathrm{~W}$ for $3 \mathrm{~min}$ ) pasteurized skim, reduced-fat and whole milk, and heavy whipping cream. During the next 4 consecutive sessions, the descriptor terms for 4 major odor attributes (eggy, nutty, rubbery, and creamy) were short-listed from the initial list by consensus. In the fifth week of sessions, panelists were calibrated to a $15-\mathrm{cm}$ line scale for intensity for each attribute. The final list of descriptor terms, along with the reference samples used to anchor panelists, is shown in Table 1. All the samples were refrigerated after preparation and were tempered to approximately $10 \pm 1^{\circ} \mathrm{C}$ before the training session. The panelists were provided with descriptor sheets with $15-\mathrm{cm}$ line scales to mark the intensities of each odor attribute, remembering the scores of the reference samples used during the training sessions.

Panelists evaluated the control (commercial pasteurized milk) and the most extreme Ts sample (average power of $115 \mathrm{~W}$ for $3 \mathrm{~min}$ ) weekly, during the storage period of $4 \mathrm{wk}$, in 3 replications. To minimize fatigue, panelists evaluated only a few samples at a time, which necessitated a balanced incomplete block design. During each evaluation session, samples were from freshly opened Nalgene bottles that had been stored at $4^{\circ} \mathrm{C}$, and delivered to individual glass jars, coded with 3 -digit numbers, and with threaded lids for sniffing. Samples were served at $10 \pm 1^{\circ} \mathrm{C}$. A standard procedure for sniffing samples was followed by all panelists. The glass sample containers (30-mL volume; US Plastic Corp., Lima, OH), with lids closed, were placed on the palm and enclosed by fingers. The container was slowly swirled for approximately $20 \mathrm{~s}$; shaking containers was 
Table 1. References (anchors) used for training panelists on varying intensities of odor attributes in thermosonicated skim milk and cream

\begin{tabular}{llc}
\hline $\begin{array}{l}\text { Odor } \\
\text { descriptor }\end{array}$ & Reference & $\begin{array}{c}\text { Intensity } \\
\text { of } \\
\text { attribute }\end{array}$ \\
\hline Eggy & Fresh hard-boiled eggs & 15 \\
& Fresh custard (2 cups of scalded 2\% milk, 2 beaten egg yolks, 1/3 cup of sucrose) & 7.5 \\
& Custard, stored 2 d in refrigerator & 2 \\
Nutty & Pasteurized (HTST) skim milk & 1 \\
& Pecan nuts toasted for 3 min & 15 \\
Rubbery & Pecan nuts toasted for 1 min & 10 \\
& Fresh custard & 3.5 \\
Creamy & Pubber bands & 15 \\
& Pasteurized (HTST) skim milk & 2 \\
& Pasteurized (HTST) heavy whipping cream & 15 \\
& Pasteurized (HTST) whole milk & 5 \\
& Pasteurized (HTST) skim milk & 1 \\
\hline
\end{tabular}

not recommended because foam formation might interfere with sniffing. The lids were opened and samples were evaluated immediately by a deep sniff with the nose close to the brim of the container. No more than 2 or 3 sniffs were recommended for evaluating a sample to avoid fatigue arising from continuous sniffing. Panelists marked the intensity of the odor attribute on a 15-cm line scale.

\section{Data Analysis}

Analyses were performed in duplicate on individual milk and cream samples for all experiments except for sensory evaluation, which was done in triplicate. Results were analyzed by ANOVA using SAS (version 9.2; SAS Institute Inc., Cary, NC) and XLStat (version 2013.4; Addinsoft, New York, NY). A significance level of $\alpha=0.05$ with Tukey adjustment for multiple comparisons was used to determine significant differences.

\section{RESULTS AND DISCUSSION}

\section{Total Plasmin Assay}

The PL activity of the raw cream fraction $(26.13 \pm$ $5.07 \mathrm{mU} / \mathrm{mL}$ ) was almost 1.5 times higher than that of the raw skim milk fraction $(17.64 \pm 1.30 \mathrm{mU} / \mathrm{mL})$ separated from the raw whole milk $(P<0.05)$. Both heating and Ts decreased total PL activity, but Ts was more effective in initially reducing and maintaining lower residual levels of total PL activity than thermal treatments of skim milk and cream (Figure 1a and b); total PL activity decreased with increase in heating or Ts treatment time. However, an increase in Ts amplitude did not directly correlate with decreased total PL activity, particularly in skim milk; the $104 \mathrm{~W}$ treatment yielded a greater decrease in PL activity than the 115
$\mathrm{W}$ treatment, for both 1 and $3 \mathrm{~min}$. Thermal treatment caused an approximate 24 to $50 \%$ decrease in total PL activity in skim milk, whereas Ts caused an approximate 73 to $94 \%$ decrease. Similarly, in cream, thermal treatment decreased total PL activity by about 63 to $88 \%$, whereas TS decreased the activity by about $95 \%$. Irreversible inactivation of PL begins above $65^{\circ} \mathrm{C}$, as reported by Metwalli et al. (1998). Borda et al. (2004) reported that heating PL in phosphate buffer medium to $85^{\circ} \mathrm{C}$ for $5 \mathrm{~min}$ could completely inactivate the enzyme. When PL was heated to $74^{\circ} \mathrm{C}$ for 120 to 600 $\mathrm{s}$ in a milk salt solution, an approximate 10 to $80 \%$ reduction in enzyme activity was observed (Metwalli et al., 1998). Treatment medium plays a major role in PL inactivation, because the presence of $\beta-\mathrm{LG}$, casein, free -SH groups, and enzyme activators and inhibitors can influence enzyme activity and inactivation (Alichanidis et al., 1986). Note that the thermal treatments used in our research were $72^{\circ} \mathrm{C}$ for 1 and $3 \mathrm{~min}, 4$ to 12 times longer treatment times compared with commercial pasteurization. Longer exposure of the unfolded enzyme to thermal treatment likely results in protein-protein reactions and enzyme inactivation. Further, the PL activity in cream samples that were subjected to thermal treatment only gradually increased during the refrigerated period, implying that the enzyme was neither completely nor irreversibly inactivated by the thermal treatment conditions used in the present study.

Although different enzymes were evaluated, the results support those of Villamiel and de Jong (2000b), who reported that ultrasonication at $150 \mathrm{~W}$, after heating to $61^{\circ} \mathrm{C}$, decreased the activity of alkaline phosphatase by approximately $49 \%$ in whole milk and $44 \%$ in skim milk, whereas conventional heating at $70^{\circ} \mathrm{C}$ decreased alkaline phosphatase activity by only $24 \%$ in both whole and skim milk. Research has shown that ultrasound acts synergistically with heat to inactivate 
enzymes in food systems (Lopez et al., 1994; Villamiel and de Jong, 2000b; Vercet et al., 2002). The postulated theory is that higher temperatures can yield unfolding of the native structure enzymes (Metwalli et al., 1998) and thus increase the efficiency of the inactivation mechanism of ultrasound.

Total PL activity in thermosonicated skim milk samples increased 5- to 10-fold during the 30 -d storage period $\left(4 \pm 1^{\circ} \mathrm{C}\right)$, but on $\mathrm{d} 30$, values were still less than $100 \%$ of the initial activity of raw skim milk (Figure 1a). On d 30, total PL activities of skim milk that was thermally treated at $72^{\circ} \mathrm{C}$ for 3 min were just over $100 \%$
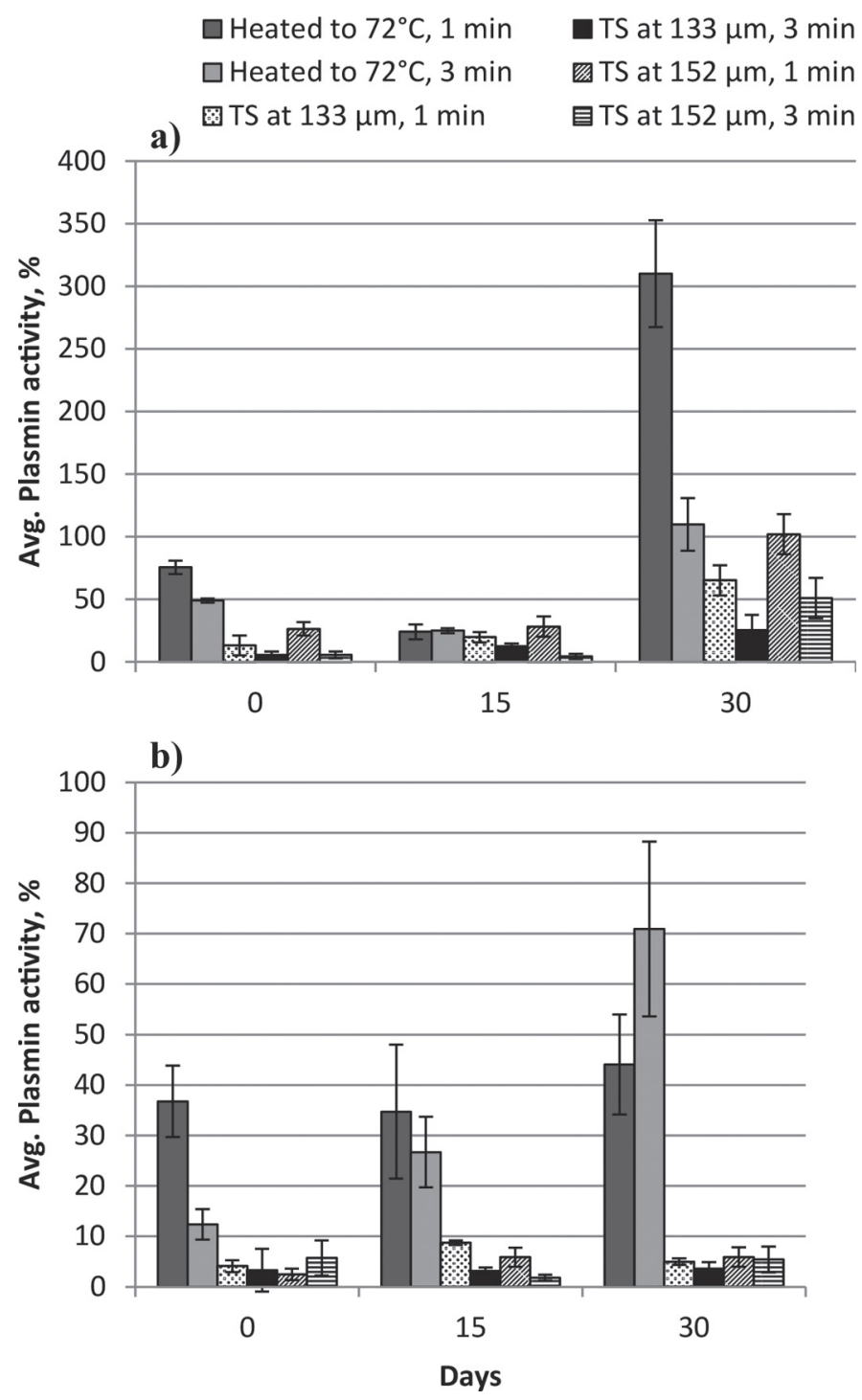

Figure 1. Effect of thermal treatments and thermosonication (Ts) on total plasmin activity (\%) in (a) skim milk and (b) cream in relation to the untreated control $(100 \%)$; results are means of 3 replications \pm SD. of the raw skim milk PL activity. In contrast, on d 30, total PL activities of skim milk samples thermally treated at $72^{\circ} \mathrm{C}$ for 1 min were more than $300 \%$ of raw skim milk PL activity. Refolding of the nonactive enzyme back to its native state after the shorter treatment time likely enabled the enzyme to become active during the 30-d storage period. Researchers have reported that PL is a robust enzyme with a high conformational stability; even though PL readily unfolds upon heating, the unfolded enzyme is resistant to degradation reactions and, upon cooling, the unfolded enzyme refolds into its active state again (Metwalli et al., 1998). Metwalli et al. (1998) found that when PL was incubated at $54^{\circ} \mathrm{C}$ for $13 \mathrm{~h}$ or at $65^{\circ} \mathrm{C}$ for $10 \mathrm{~min}$ and subsequently cooled to $37^{\circ} \mathrm{C}$, PL activity was completely restored, which implies refolding of the enzyme back to its active state. The thermal stability of the PL enzyme could be due to its robustness; that is, either a strong conformational stability or high resistance offered by the unfolded enzyme to subsequent degradative reactions permitting the unfolded enzyme to refold back into its active state upon cooling. The PL system is complicated and the effects of Ts on individual components of the system such as inhibitors and activators as well as casein (which offers substrate protection to PL) and $\beta$-LG (which inhibits PL activity through protein-protein interactions) will need to be investigated to completely understand the effects on total PL activity. Nonetheless, these results support the idea that regeneration of total PL activity in thermosonicated skim milk is slower than in skim milk subjected to thermal treatment alone, which demonstrates the potential of ultrasound in improving the shelf life of fluid milk.

Total PL activity after Ts remained lower in cream samples than in skim milk samples throughout the entire 30 -d storage period $\left(4 \pm 1^{\circ} \mathrm{C}\right)$; PL activity was maintained below $10 \%$ of the raw cream values (Figure 1b). Thermally treated cream remained at or below $72 \%$ of the initial total PL activity of raw cream. Although no reports are available regarding the effect of milk fat on protection of enzymes during Ts, researchers have reported that fat influences thermal inactivation of lactoperoxidase (but not alkaline phosphatase) and denaturation of $\beta$-LG (Claeys et al., 2002). Denaturation of $\beta-\mathrm{LG}$ is enhanced at higher milk fat content at temperatures $>72^{\circ} \mathrm{C}$ (Claeys et al., 2002). BermúdezAguirre and Barbosa-Cánovas (2008) also found that fat could protect bacteria from denaturation caused by cavitation when treated at $120 \mu \mathrm{m}$ amplitude for 30 min at $63^{\circ} \mathrm{C}$. This treatment resulted in less inactivation of Listeria in full-fat milk than in skim milk. The Ts conditions in the present study were more effective in reducing the total PL activity in cream than 
Table 2. Lightness ( $\mathrm{L}^{*}$; mean $\pm \mathrm{SD}$ ) values of raw, heated, and thermosonicated (Ts) skim milk and cream on d 1, 15, and 30 of refrigerated storage

\begin{tabular}{|c|c|c|c|c|c|c|}
\hline \multirow[b]{2}{*}{ Treatment } & \multicolumn{3}{|c|}{ Skim milk } & \multicolumn{3}{|c|}{ Cream } \\
\hline & d 1 & d 15 & d 30 & d 1 & d 15 & d 30 \\
\hline Raw & $77.36^{\mathrm{a}-\mathrm{d}} \pm 0.65$ & Not stored $^{1}$ & Not stored & $82.81^{\mathrm{A}-\mathrm{D}} \pm 0.40$ & Not stored & Not stored \\
\hline Heated to $72^{\circ} \mathrm{C}, 1 \mathrm{~min}$ & $77.29^{\mathrm{a}-\mathrm{d}} \pm 0.15$ & $78.23^{\mathrm{a}-\mathrm{c}} \pm 0.18$ & $75.78^{\mathrm{d}} \pm 0.55$ & $84.93^{\mathrm{A}-\mathrm{C}} \pm 0.56$ & $79.28^{\mathrm{D}} \pm 3.58$ & $79.63^{\mathrm{CD}} \pm 0.69$ \\
\hline Heated to $72^{\circ} \mathrm{C}, 3 \mathrm{~min}$ & $77.85^{\mathrm{a}-\mathrm{d}} \pm 0.87$ & $77.11^{\mathrm{a}-\mathrm{d}} \pm 0.94$ & $76.23^{\mathrm{cd}} \pm 0.07$ & $84.40^{\mathrm{A}-\mathrm{D}} \pm 2.92$ & $81.29^{\mathrm{A}-\mathrm{D}} \pm 0.33$ & $79.19^{\mathrm{D}} \pm 1.02$ \\
\hline Ts at $133 \mu \mathrm{m}(104 \mathrm{~W}), 1 \mathrm{~min}$ & $77.52^{\mathrm{a}-\mathrm{d}} \pm 0.67$ & $78.42^{\mathrm{ab}} \pm 0.90$ & $76.76^{\mathrm{b}-\mathrm{d}} \pm 0.21$ & $86.44^{\mathrm{A}} \pm 1.12$ & $83.67^{\mathrm{A}-\mathrm{D}} \pm 0.28$ & $80.59^{\mathrm{B}-\mathrm{D}} \pm 0.86$ \\
\hline Ts at $133 \mu \mathrm{m}, 3 \mathrm{~min}$ & $78.57^{\mathrm{ab}} \pm 0.09$ & $79.06^{\mathrm{a}} \pm 0.03$ & $76.86^{\mathrm{b}-\mathrm{d}} \pm 0.04$ & $86.48^{\mathrm{A}} \pm 1.17$ & $83.60^{\mathrm{A}-\mathrm{D}} \pm 0.47$ & $80.23^{\mathrm{CD}} \pm 0.98$ \\
\hline
\end{tabular}

in skim milk, implying that the fat did not protect the PL system from inactivation upon Ts. Pasteurization (incorporated into all treatments in the present study) inactivates plasminogen inhibitors, yet PA are heat stable. Additionally, because PL, PG, and PA are associated with casein micelles, the fact that these substrates are more concentrated in skim milk than cream may partially explain the higher total PL activity of treated skim milk than treated cream, particularly with extended storage. Future studies should be designed to isolate the short- and long-term effect of Ts on PL, PG, and PA.

\section{Lightness}

Extreme high-temperature processing of milk such as UHT processing induces Maillard reactions, which can lead to color changes (van Boekel, 1998; Elliott et al., 2005). The appearance of milk can be measured based on tristimulus parameters in the $\mathrm{L}^{*} \mathrm{a}^{*} \mathrm{~b}^{*}$ mode; $\mathrm{L}^{*}$ values range from 0 (black) to 100 (white) and represent lightness or reflectance of milk, which is related to the presence of casein micelles and fat globules in milk. Researchers have shown that microwave-processed milk products have brownish hues compared with UHT milk (Clare et al., 2005), and the lightness of high-pressureprocessed milk was less than that of pasteurized milk (Pereda et al., 2007).

Not surprisingly, treated cream samples (heat or Ts) had significantly lighter appearance (higher $\mathrm{L}^{*} ; P<$ 0.001) compared with skim milk samples (Table 2). However, the $\mathrm{L}^{*}$ values of raw skim milk and cream samples did not differ from those of any other samples of the same fat content $(P>0.05)$. The Ts skim milk and cream samples tended to have numerically higher $\mathrm{L}^{*}$ values than heated or control samples on the same day of analysis, but differences were not typically significant. The Ts amplitude and time were not significant main effects; storage time (a significant main effect) had a greater effect on $\mathrm{L}^{*}$ than did treatment. The $\mathrm{L}^{*}$ values tended to be highest on $\mathrm{d} 1$ and lowest on d 30, suggesting initial dissociation of casein micelles. Dissociation of micelles results in lower $\mathrm{L}^{*}$ values because of decreased micellar size and light scattering (Huppertz et al., 2002; O'Sullivan et al., 2002). Ultrasonic treatment $(35 \mathrm{kHz}, 200 \mathrm{~W})$ for $6 \mathrm{~h}$ is capable of disrupting reassembled casein micelles (without breaking the peptide bond of casein chains) in casein solutions, with the magnitude of disruption increasing with increasing output power (Madadlou et al., 2009). The $\mathrm{L}^{*}$ values from our work were slightly lower than those of Bermúdez-Aguirre et al. (2008), who investigated the effects of ultrasound $(24 \mathrm{kHz}, 120 \mu \mathrm{m}$ amplitude, 400 $\left.\mathrm{W}, 63^{\circ} \mathrm{C}, 30 \mathrm{~min}\right)$ on the color properties of raw $(\sim 4 \%$ fat) whole milk. Thermosonicated milk had higher $\mathrm{L}^{*}$ values than heated and raw milk samples. Further, Ts decreased the size of milk fat globules (smaller than 1 $\mu \mathrm{m}$ ) and surfaces appeared roughened because of interactions with some casein micelles (Bermúdez-Aguirre et al. 2008). Results of the present study show that the lightness values after Ts (at any treatment) were not significantly different within skim milk or cream treatments (when measured on d 1). Differences beyond d 1 , although significant, would not likely be notable by consumers, implying that the TS treatment conditions selected for this study would not adversely affect the appearance of skim milk or cream. Our results are in line with Khanal et al. (2014), who recently reported no significant changes in $\mathrm{L}^{*}$ value of milk after 1 or $5 \mathrm{~min}$ of ultrasonication.

\section{Viscosity}

Factors such as particle size (Floury et al., 2000), casein micelle aggregates (Walstra and Jenness, 1984), and heat denaturation of whey proteins (Clare et al., 2005) can affect the viscosity of milk, which in turn affect mouthfeel, acceptability, and shelf life of milk. No 
Table 3. Viscosity $\left(\times 10^{-3} \mathrm{~Pa} \cdot \mathrm{s}\right.$; mean $\left.\pm \mathrm{SD}\right)$ of raw, heated, and thermosonicated $(\mathrm{Ts})$ skim milk and cream on $\mathrm{d} 1,15$, and 30 of refrigerated storage

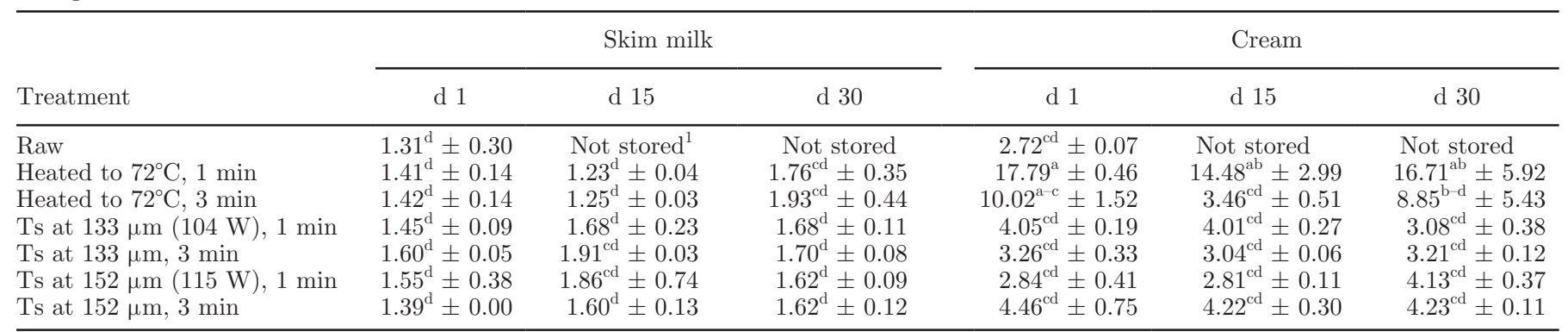

${ }^{\mathrm{a}-\mathrm{d}}$ Means with the same superscript do not significantly differ $(P<0.05)$.

${ }^{1}$ Not stored because of spoilage concerns.

significant differences were found in the viscosity values of skim milk samples because of heating or Ts or over the 30-d period (Table 3). Additionally, no significant differences were observed between raw and thermosonicated cream samples (even though Ts resulted in particle size reduction in cream samples) or cream heated for $3 \mathrm{~min}$. In contrast, viscosity values of cream samples heated for $1 \mathrm{~min}$ were higher than those of raw cream samples $(P<0.0005)$. This could be because of formation of fat aggregates or clusters. Pereda et al. (2007) reported that the viscosity of milk that underwent ultra-high-pressure homogenization at $300 \mathrm{MPa}$ was greater than that of milk treated at $200 \mathrm{MPa}$ and that this was because of the formation of fat aggregates. Floury et al. (2000) also observed re-coalescence in oilin-water emulsions that were subjected to $300 \mathrm{MPa}$ of pressure. This implies that fat aggregation could occur in cream samples subjected to heat for 1 min (but not $3 \mathrm{~min}$ ), which in turn could have caused the increase in the viscosity of the sample.

Few published works have demonstrated the effects of alternative processing on the viscosity of fluid milk. Application of pulsed electric field in the range of 45 to $55 \mathrm{kV} / \mathrm{cm}$ decreased the viscosity of skim milk (Floury et al., 2006) and ultra-high-pressure homogenization (200 MPa) decreased the viscosity of whole milk (Pereda et al., 2007). Cavitation, caused by prolonged ultrasound $(20 \mathrm{kHz}, 120 \mu \mathrm{m})$ combined with heat $\left(75.5^{\circ} \mathrm{C}\right)$ for $102.3 \mathrm{~s}$, is capable of denaturing milk proteins (Villamiel and de Jong, 2000b); neither the sonication specifications nor the power value was reported. Research has shown that whey proteins, which unfold during heat denaturation, undergo sulfhydryl-disulfide interchange reactions and cause an increase in viscosity (Clare et al., 2005). Shanmugam et al. (2012) recently showed that ultrasound $(20 \mathrm{kHz}$ at 20 and $41 \mathrm{~W}$ under controlled temperature conditions for up to $60 \mathrm{~min}$ ) did not affect the viscosity of previously pasteurizedhomogenized skim milk. Thus, it is not surprising that the conditions conducted in the present work resulted in no significant adverse effects on viscosity of skim milk or cream samples over a 30 -d storage period.

\section{Milk Fat Globule Size}

Size of fat globules in unhomogenized fluid milk ranges from 0.2 to $20 \mu \mathrm{m}$ (averaging around $4 \mu \mathrm{m}$ ), depending on cow breed and season (Mulder and Walstra, 1974). The average size of the fat globules in the raw skim milk and cream samples in the current study fell within this range (Table 4$)$. No differences $(P>$ $0.05)$ in $\mathrm{D}_{3,2}, \mathrm{D}_{4,3}$, or specific area values were observed based upon days in storage (measured on d 6, 15, and 30), so pooled means are included in Table 4. Heating did not change $\mathrm{D}_{3,2}, \mathrm{D}_{4,3}$, or specific area of skim milk or cream; however, Ts caused a significant decrease $(P$ $<0.0001)$ in $\mathrm{D}_{3,2}$ and $\mathrm{D}_{4,3}$ and a significant increase in specific area of fat globules in both skim milk and cream compared with the raw and heated samples. This suggests that ultrasound caused homogenization of both skim milk and cream. One of the reasons for the homogenizing effects of ultrasound is the cavitation caused by sonication in the fluid (Ertugay et al., 2004). These results agree with those of Wu et al. (2001), who reported that longer sonication periods improved the homogenization effect in milk. Wu et al. (2001) also reported that ultrasound homogenizes milk better than the conventional system, which implies that ultrasound has a greater potential in a continuous milk pasteurization system. No significant differences were observed among the $\mathrm{D}_{3,2}, \mathrm{D}_{4,3}$, and specific area values of either thermosonicated skim milk or cream samples over the 30-d storage period (data not shown). Published studies on fat globule size of sonicated milk over storage time are scarce. Shanmugam et al. (2012) reported that the size of fat globules in previously pasteurized-homogenized skim milk decreased after 60 min of sonication. Our findings on the effect of shorter-time Ts on the size 
Table 4. Fat globule size ( $\mu \mathrm{m}$; mean $\pm \mathrm{SD})$ and specific area $\left(\mu \mathrm{m}^{2} / \mathrm{g}\right.$; mean $\left.\pm \mathrm{SD}\right)$ in raw, heated, and thermosonicated (Ts) skim milk and cream

\begin{tabular}{|c|c|c|c|c|c|c|}
\hline \multirow[b]{2}{*}{ Treatment } & \multicolumn{2}{|c|}{ Sauter diameter, $\mathrm{D}_{3,2}$} & \multicolumn{2}{|c|}{$\begin{array}{l}\text { Volume-weighted } \\
\text { diameter, } \mathrm{D}_{4,3}\end{array}$} & \multicolumn{2}{|c|}{ Specific area } \\
\hline & Skim & Cream & Skim & Cream & Skim & Cream \\
\hline Heated to $72^{\circ} \mathrm{C}, 1 \mathrm{~min}$ & $2.58^{\mathrm{c}} \pm 0.08$ & $3.95^{\mathrm{a}} \pm 0.22$ & $3.05^{\mathrm{b}} \pm 0.06$ & $5.24^{\mathrm{a}} \pm 1.07$ & $2.53^{\mathrm{d}} \pm 0.13$ & $1.65^{\mathrm{d}} \pm 0.09$ \\
\hline Heated to $72^{\circ} \mathrm{C}, 3 \mathrm{~min}$ & $2.57^{\mathrm{c}} \pm 0.03$ & $3.65^{\mathrm{b}} \pm 0.35$ & $3.01^{b} \pm 0.12$ & $4.75^{\mathrm{a}} \pm 0.92$ & $2.54^{\mathrm{d}} \pm 0.00$ & $1.80^{\mathrm{d}} \pm 0.18$ \\
\hline Ts at $133 \mu \mathrm{m}(104 \mathrm{~W}) 1 \mathrm{~min}$ & $0.35^{\mathrm{fg}} \pm 0.06$ & $0.71^{\mathrm{d}} \pm 0.04$ & $0.91^{\mathrm{c}} \pm 0.50$ & $2.80^{\mathrm{b}} \pm 1.10$ & $19.22^{\mathrm{b}} \pm 0.08$ & $9.18^{\mathrm{c}} \pm 0.49$ \\
\hline Ts at $152 \mu \mathrm{m}, 3 \mathrm{~min}$ & $0.22^{\mathrm{g}} \pm 0.03$ & $0.62^{\mathrm{de}} \pm 0.07$ & $0.48^{\mathrm{c}} \pm 0.11$ & $1.22^{\mathrm{c}} \pm 0.06$ & $29.69^{\mathrm{a}} \pm 0.12$ & $10.55^{\mathrm{c}} \pm 1.16$ \\
\hline
\end{tabular}

${ }^{\mathrm{a}-\mathrm{g}}$ Means within the each set of columns $\left(\mathrm{D}_{3,2}, \mathrm{D}_{4,3}\right.$, or specific area) with the same letter do not significantly differ $(P<0.05)$.

of milk fat globules in raw skim milk and cream over a period of $30 \mathrm{~d}$ shed more light on the potential application of ultrasound for homogenization along with pasteurization in continuous processing lines.

\section{Microbiological Analysis}

The mean TAC of the raw milk, raw skim milk, and raw cream were $3.92,3.86$, and $3.97 \log \mathrm{cfu} / \mathrm{mL}$, respectively (data not shown). The high mean coliform count (fecal indicator organisms) in the raw milk (3.65 $\log \mathrm{cfu} / \mathrm{mL}$ ) in the present study was likely due to unhygienic milk collection from the bulk tank exit port by the staff person, rather than a true indicator of the quality of the milk inside the bulk tank.

Conventional pasteurization conditions were selected to effectively destroy all pathogens $(5 \mathrm{log})$ from milk, but some spoilage microorganisms survive pasteurization and proliferate even under refrigeration. Because Ts is being considered as an adjunct to, not a replacement for, pasteurization, the effectiveness of ultrasound to kill bacteria was not independently evaluated without heat, because Ts included preheating equivalent to pasteurization $\left(72^{\circ} \mathrm{C}\right.$ and held for at least $\left.15 \mathrm{~s}\right)$. Furthermore, ultrasound is not approved as a legal pasteurization technique. As expected, heating $\left(72^{\circ} \mathrm{C}\right.$ for 1 and $3 \mathrm{~min}$ ) effectively eliminated $(>3.6 \log$ reduction) coliforms in skim milk and cream; no coliforms grew on plates poured on d 1, 15, or 30 (data not shown). Additionally, all heat and TS treatments caused more than $1.86 \mathrm{log}$ reductions of total aerobic bacteria, in both skim milk and cream (data not shown). Earlier work by Cameron et al. (2008, 2009) reported that ultrasound $\left(20 \mathrm{kHz}, 750 \mathrm{~W}, 24\right.$ to $26^{\circ} \mathrm{C}$, in ice bath, for 6 to $10 \mathrm{~min}$ ) completely eliminated coliforms and yielded $\geq 99 \%$ reduction of pathogens (Escherichia coli; Listeria monocytogenes) and spoilage microorganisms (Pseudomonas fluorescens) inoculated into sterile whole milk (3.4\% fat). More recently, sterile skim milk was inoculated with vegetative cells of spoilage microorganisms Bacillus coagulans and Anoxybacillus flavithermus (Khanal et al., 2014). When $10 \mathrm{~min}$ of sonication $(80 \%$ amplitude, $114 \mu \mathrm{m}$ maximum, in an ice bath) was followed by pasteurization, the treatment resulted in complete inactivation of cells; inactivation was incomplete with sonication alone and at lower sonication times (1 or $5 \mathrm{~min}$ ) followed by pasteurization. Those investigators did not report counts beyond the initial counts and treatment times were longer than those in the present work. Our findings support that ultrasound is effective against bacteria and additionally demonstrates that the addition of heat can deliver similar effects, but with shorter sonication times.

After $30 \mathrm{~d}$ of refrigerated storage, TAC of all skim milk and cream, heat treated or thermosonicated, remained lower than $3 \log \mathrm{cfu} / \mathrm{mL}$, well below the 4.3 $\log \mathrm{cfu} / \mathrm{mL}(<20,000 \mathrm{cfu} / \mathrm{mL})$ standard established by the USDA Department of Health and Human Services (FDA, 2009) for Grade A pasteurized milk, indicating that the samples had not reached the end of their microbiological shelf life by d 30. One exception was found for skim milk thermosonicated at $133 \mu \mathrm{m}$ for 3 min, where counts exceeded $3.4 \mathrm{log} \mathrm{cfu} / \mathrm{mL}$ (data not shown). The dilution range selected to determine TAC did not enable enumeration of more than 250 countable colonies $(2,500 \mathrm{cfu} / \mathrm{mL}$ or $3.40 \log \mathrm{cfu} / \mathrm{mL})$, thus we cannot say with confidence that the skim milk sample thermosonicated at an average power of $104 \mathrm{~W}$ for 3 min did not exceed 20,000 cfu/mL $(4.3 \mathrm{log} \mathrm{cfu} / \mathrm{mL})$ on d 30. For comparison, the Ts $(24 \mathrm{kHz}, 200 \mathrm{~W}$, for 0, 2 , 4,8 , or $16 \mathrm{~min}$, in an ice bath) conducted by Chouliara et al. (2010) on raw, thermized, and pasteurized whole milk (3.5\% fat) resulted in 1.0- to 2.1-log reductions in total viable counts and psychrotrophs, but in contrast to our findings, none of the milk, regardless of treatment, maintained counts below $4.3 \log \mathrm{cfu} / \mathrm{mL}$ for even $6 \mathrm{~d}$ of storage. Differences may be explained by the fact that the milk temperature was maintained very 
Table 5. Intensity of creamy odor of control (commercial pasteurized milk) and skim milk and cream thermosonicated at $152 \mu \mathrm{m}(115 \mathrm{~W})$ for 3 min and refrigerated for up to $29 \mathrm{~d}^{1}$

\begin{tabular}{lcccccc}
\hline Sample & Day 1 & Day 8 & Day 15 & Day 22 & Day 29 & $\begin{array}{c}\text { Control } \\
\text { (untreated) }\end{array}$ \\
\hline Skim milk & 2.16 & 2.55 & 2.79 & 2.43 & 2.95 & 1.38 \\
Cream & $10.27^{\mathrm{ab}}$ & $8.72^{\mathrm{b}}$ & $10.84^{\mathrm{ab}}$ & $11.83^{\mathrm{a}}$ & $11.63^{\mathrm{a}}$ & 2.59 \\
\hline
\end{tabular}

a,b Different superscripts indicate that significant differences exist between mean values within a row $(P<0.05)$.

${ }^{1}$ Means of triplicate evaluations by 8 trained panelists using 15 -cm line scale.

close to $72^{\circ} \mathrm{C}$ (not in an ice bath) in the present study. The synergistic effect of heat and ultrasound has been reported previously (Lopez et al., 1994; Villamiel and de Jong, 2000b; Vercet et al., 2002).

The findings of the present work suggest that the Ts treatments selected for this study may be adequate to maintain microbial milk quality for up to $30 \mathrm{~d}$, but additional research must be conducted to confirm the effectiveness of ultrasound against particularly resilient bacteria and at even lower Ts holding times, which may be more feasible in the dairy industry.

\section{Odor Evaluation-Descriptive Analysis}

During training sessions, the panelists established that nutty and creamy aromas represented desirable attributes for skim and cream, whereas eggy and rubbery aromas represented offensive attributes that can result from over-processing the milk. To minimize fatigue of panelists, evaluation was conducted only on controls (commercial pasteurized milk) and samples treated with the highest intensity Ts (average power of $115 \mathrm{~W}$ ). Offensive off-aromas may be the result of protein or lipid reactions (Riener et al., 2009; Chouliara et al., 2010; Pingret et al., 2012). The mean intensities of aroma attributes for all control and Ts-treated samples (except creamy attribute for cream samples) were low $(<3.8)$ to intermediate $(<7.5)$ on the standard 15 -cm line scale (Table 5). Few significant differences were found among control and thermosonicated (average power of $115 \mathrm{~W}$ ) samples, regardless of whether sample means were pooled or if skim milk and cream were analyzed separately. Odor differences tended to be a consequence of fat content or storage time rather than Ts. Creamy aroma was higher $(P<0.0001)$ for cream (10.68) than for skim milk (2.37), which is why skim milk and cream are separately delineated in Table 5. Eggy, nutty, and rubbery attribute mean scores did not significantly differ based upon fat content $(P>$ 0.05 ), which is why overall mean scores for skim and cream samples are combined in Table 6 .

Mean scores for the eggy aroma attribute started out (wk 0) and remained low during the 4-wk storage period $(<3.5 \mathrm{~cm})$ and did not differ from those of untreated controls (Table 6). Nutty and rubbery aroma scores were low to intermediate $(<7.5 \mathrm{~cm})$ throughout the study (Table 6). Mean nutty aroma of control (untreated) samples and Ts samples stored for 2, 3, and 4 wk had significantly lower mean scores than Ts samples evaluated on wk 0 . A similar but nonsignificant $(P>$ 0.05 ) decrease in rubbery aroma beyond wk 0 was observed (Table 6).

Previous investigators reported that thermosonicating pasteurized homogenized milk of $1.5 \%$ fat content continuously $\left(24 \mathrm{kHz}, 400 \mathrm{~W}, 45^{\circ} \mathrm{C}\right)$ from 2.5 to 20 min resulted in an undesirable rubbery aroma; however, the intensity of rubbery odor decreased with a decrease in ultrasound power from 400 to $100 \mathrm{~W}$ (Riener et al., 2009). It should be noted that Riener et al. (2009) reported the effects of Ts on a commercial $1.5 \%$ milk sample that had been already pasteurized. Because the milk had undergone 2 steps of thermal processing; that is, commercial pasteurization and Ts, formation of volatile compounds that create off-odors

Table 6. Intensity of eggy, rubbery, and nutty odor attributes of control (commercial pasteurized milk) and skim milk and cream ${ }^{1}$ thermosonicated at $152 \mu \mathrm{m}(115 \mathrm{~W})$ for $3 \mathrm{~min}$, refrigerated for up to $29 \mathrm{~d}$

\begin{tabular}{lcccccc}
\hline Odor $^{2}$ & Day 1 & Day 8 & Day 15 & Day 22 & Day 29 & $\begin{array}{c}\text { Control } \\
\text { (untreated) }\end{array}$ \\
\hline Eggy & 3.15 & 3.08 & 2.77 & 2.73 & 2.21 & 2.04 \\
Rubbery & 6.38 & 5.55 & 4.97 & 5.40 & 4.88 & 5.30 \\
Nutty & $5.35^{\mathrm{a}}$ & $3.98^{\mathrm{ab}}$ & $3.15^{\mathrm{bc}}$ & $2.73^{\mathrm{bc}}$ & $2.47^{\mathrm{bc}}$ & 2.04 \\
\hline
\end{tabular}

\footnotetext{
${ }^{a-c}$ Different superscripts indicate that significant differences exist between mean values within a row $(P<0.05)$.

${ }^{1}$ Attribute mean scores did not significantly differ based upon fat content $(P>0.05)$; thus, skim milk and cream were combined to show day effect for nutty odor.

${ }^{2}$ Means of triplicate evaluations by 8 trained panelists using 15 -cm line scale.
} 
might have been favored, which is why we started with raw milk. The increase of offensive odors in thermosonicated samples reported in previous works could be the result of chemical reactions taking place in the regions of high temperature and pressure, such as the interface of collapsing bubbles and surrounding liquid phase, and the formation of free radicals by pyrolysis (Makino et al., 1983; Riesz and Kondo, 1992; Henglein, 1995; Riener et al., 2009). Free radicals such as $\mathrm{H}^{\bullet}$ and $\mathrm{OH}^{\bullet}$ can induce auto-oxidation of lipids in milk, resulting in the formation of aldehydes such as pentanal, hexanal, and heptanal (Toma et al., 2001; Karatapanis et al., 2006). Chemat et al. (2004) stated that the nature of the sonication-induced chemical reactions that cause undesirable odors in sunflower oil are not associated with just 1 or 2 components. Further, gas chromatography-olfactometry experiments conducted by Riener et al. (2009) showed that none of the volatile compounds that arise or increase during sonication appear to make significant individual contributions to the rubbery odor of the sonicated milk samples because of their weak and ill-defined aromas. However, a subjective descriptive analysis of odor attributes, which could explain whether ultrasound induces any detectable, undesirable odor in milk, was not performed.

In the present study, very few significant differences between thermosonicated and control samples were found for any of the odor attributes. When treatment (control vs. Ts) was treated as the main effect, no significant difference $(P>0.05)$ was found for eggy, rubbery, or creamy attributes. Only the pleasant nutty aroma was higher $(P=0.002)$ for Ts samples (3.56) than controls (2.08), but as indicated earlier, the nutty aroma dissipated after d 0 (Table 6 ). The low to intermediate $(<7.5 / 15.0)$ intensity scores for eggy and rubbery aroma attributes suggest that the most extreme conditions of Ts (average power of $115 \mathrm{~W}$ ) used in the present study did not induce strong or persistent undesirable aromas in skim milk or cream. The descriptive analysis results suggest promise for commercial Ts of milk under relatively mild conditions.

\section{CONCLUSIONS}

Ultrasound combined with heat $\left(72^{\circ} \mathrm{C}\right)$ for 1 to 3 min is capable of decreasing the total plasmin activity in fresh skim milk and cream by approximately $94 \%$. In the present study, total plasmin activity increased in thermosonicated skim milk over a storage period of $30 \mathrm{~d}$ but did not vary significantly in thermosonicated cream over the same storage period, suggesting different effects of Ts on skim milk and cream. Rheological experiments showed that Ts did not cause any adverse changes in skim milk and cream over a 30-d period.
Thermosonication did not cause significant differences in the lightness $\left(\mathrm{L}^{*}\right)$ value or adversely change the appearance of skim milk and cream. Thermosonication caused a significant reduction in fat globule size in both skim milk and cream and thus had a homogenizing effect. Thermosonication completely destroyed all coliforms and caused a $>99 \%$ reduction in total bacterial count in both skim milk and cream. Total aerobic bacteria counts of skim milk and cream on d 30 were still within the limits established by the Food and Drug Administration for Grade A pasteurized milk. Results of descriptive analysis showed that the extreme conditions of Ts used in the research experiments did not significantly increase the intensity of offensive rubbery and eggy odor attributes in skim milk and cream. The outcome of this research lays the groundwork for future work to establish the feasibility of ultrasound in commercial dairy processing to extend milk shelf life.

\section{ACKNOWLEDGMENTS}

The authors thank the Department of Food Science and Human Nutrition, Iowa State University (Ames, IA) for supporting this research study. We appreciate that Stephanie Jung (Iowa State University) served on the graduate program of study committee and allowed for use of the particle size analyzer and the rheometer. Appreciation is extended to the ISU Center for Crops Utilization Research pilot plant manager, Hui Wang, for supervision at the facility. We also acknowledge the contributions of time and expertise by our trained panelists. The authors also express special thanks to Branson Ultrasonics (Danbury, CT) for donating the high-power ultrasonics equipment.

\section{REFERENCES}

Alichanidis, E., J. H. M. Wrathall, and A. T. Andrews. 1986. Heat stability of plasmin (milk proteinase) and plasminogen. J. Dairy Res. 53:259-269.

Allen, J. C., and G. Joseph. 1985. Review article: Deterioration of pasteurized milk on storage. J. Dairy Res. 52:469-486.

Bastian, E. D., and R. J. Brown. 1996. Plasmin in milk and dairy products: An update. Int. Dairy J. 6:435-457.

Bendicho, S., A. R. Marselles-Fontanet, G. V. Barbosa-Canovas, and O. Martin-Belloso. 2005. High intensity pulsed electric fields and heat treatments applied to a protease from Bacillus subtilis. A comparison study of multiple systems. J. Food Eng. 69:317-323.

Bermúdez-Aguirre, D., and G. V. Barbosa-Cánovas. 2008. Study of butter fat content in milk on the inactivation of Listeria innocua ATCC 51742 by thermos-sonication. Innov. Food Sci. Emerg. Technol. 9:176-185.

Bermúdez-Aguirre, D., R. Mawson, and G. V. Barbosa-Cánovas. 2008. Microstructure of fat globules in whole milk after thermosonication treatment. J. Food Sci. 73:E325-E332.

Bilbao-Sainz, C., F. L. Younce, B. Rasco, and S. Clark. 2009. Protease stability in bovine milk under combined thermal-high hydrostatic pressure treatment. Innov. Food Sci. Emerg. Technol. 10:314-320. 
Boor, K. J. 2001. Fluid dairy product quality and safety: Looking to the future. J. Dairy Sci. 84:1-11.

Boor, K. J., and D. N. Nakimbugwe. 1998. Quality and stability of $2 \%$ fat ultrapasteurized fluid milk products. Dairy Food Environ. Sanit. 18:78-82.

Borda, D., Indrawati, C. Smout, A. Van Loey, and M. Hendrickx. 2004. High pressure thermal inactivation kinetics of a plasmin system. J. Dairy Sci. 87:2351-2358.

Bylund, G. 1995. Handbook of Dairy Processing. Tetra Pak Processing Systems AB, Lund, Sweden.

Cameron, M., L. D. McMaster, and T. J. Britz. 2008. Electron microscopic analysis of dairy microbes inactivated by ultrasound. Ultrason. Sonochem. 15:960-964.

Cameron, M., L. D. McMaster, and T. J. Britz. 2009. Impact of ultrasound on dairy spoilage microbes and milk components. Dairy Sci. Technol. 89:83-98.

Chapman, K. W., H. T. Lawless, and K. J. Boor. 2001. Quantitative descriptive analysis and principal component analysis for sensory characterization of ultrapasteurized milk. J. Dairy Sci. 84:12-20.

Chemat, F., I. Grondin, P. Costes, L. Moutoussamy, A. S. C. Sing, and J. Smadja. 2004. High power ultrasound effects on lipid oxidation of refined sunflower oil. Ultrason. Sonochem. 11:281-285.

Chouliara, E., K. G. Georgogianni, N. Kanellopoulou, and M. G. Kontominas. 2010. Effect of ultrasonication on microbiological, chemical and sensory properties of raw, thermized and pasteurized milk. Int. Dairy J. 20:307-313.

Christensen, K. R., and G. A. Reineccius. 1992. Gas chromatographic analysis of volatile sulfur compounds from heated milk using static headspace sampling. J. Dairy Sci. 75:2098-2104.

Claeys, W. L., A. M. Van Loey, and M. E. Hendrickx. 2002. Kinetics of alkaline phosphatase and lactoperoxidase inactivation, and of $\beta$-lactoglobulin denaturation in milk with different fat content. J. Dairy Res. 69:541-553.

Clare, D. A., W. S. Bang, G. Cartwright, M. A. Drake, P. Coronel, and J. Simunovic. 2005. Comparison of sensory, microbiological, and biochemical parameters of microwave versus indirect UHT fluid milk during storage. J. Dairy Sci. 88:4172-4182.

Elliott, A. J., N. Datta, B. Amenu, and H. C. Deeth. 2005. Heatinduced and other chemical changes in commercial UHT milks. J. Dairy Res. 72:442-446.

Ertugay, M. F., M. Sengül, and M. Sengül. 2004. Effect of ultrasound treatment on milk homogenization and particle size distribution of fat. Turk. J. Vet. Anim. Sci. 28:303-308.

FDA. 2009. Grade "A" Pasteurized Milk Ordinance. US Dept. of Health and Human Services, Public Health Service. Accessed July 5, 2011. http://www.fda.gov/downloads/Food/FoodSafety/Product-SpecificInformation/MilkSafety/NationalConferenceonInterstateMilkShipmentsNCIMSModelDocuments/UCM209789.pdf.

Floury, J., A. Desrumaux, and J. Lardieres. 2000. Effect of highpressure homogenization on droplet size distributions and rheological properties of model oil-in-water emulsions. Innov. Food Sci. Emerg. Technol. 1:127-133.

Floury, J., N. Grosset, N. Leconte, M. Pasco, M. N. Madec, and R. Jeantet. 2006. Continuous raw skim milk processing by pulsed electric field at non-lethal temperature: Effect on microbial inactivation and functional properties. Lait 86:43-57.

Fox, P. F., and A. L. Kelly. 2006. Indigenous enzymes in milk: Overview and historical aspects - Part 1. Int. Dairy J. 16:500-516.

Fox, P. F., J. R. Whitaker, A. G. J. Voragen, and D. W. S. Wong. 2003. Significance of indigenous enzymes in milk and dairy products. Pages 263-285 (Chapter 19) in Handbook of Food Enzymology. J. Whitaker, ed. Marcel Dekker, New York, NY.

García-Risco, M. R., I. Recio, E. Molina, and R. López-Fandiño. 2003. Plasmin activity in pressurized milk. J. Dairy Sci. 86:728-734.

Henglein, A. 1995. Chemical effects of continuous and pulsed ultrasound in aqueous solutions. Ultrason. Sonochem. 2:S115-S121.

Huppertz, T., A. L. Kelly, and P. F. Fox. 2002. Effects of high pressure on constituents and properties of milk. Int. Dairy J. 12:561-572.

Ismail, B., and S. S. Nielsen. 2010. Invited review: Plasmin protease in milk: Current knowledge and relevance to dairy industry. J. Dairy Sci. 93:4999-5009.
Jayasooriya, S. D., B. R. Bhandari, P. Torley, and B. R. D'Arcy. 2004 Effect of high power ultrasound waves on properties of meat: A review. Int. J. Food Prop. 7:301-319.

Karatapanis, A. E., A. V. Badeka, K. A. Riganakos, I. N. Savvaidis, and M. G. Kontominas. 2006. Changes in flavour volatiles of whole pasteurized milk as affected by packaging material and storage time. Int. Dairy J. 16:750-761.

Kelly, A. L., F. O'Flaherty, and P. F. Fox. 2006. Indigenous proteolytic enzymes in milk: A brief overview of the present state of knowledge. Int. Dairy J. 16:563-572.

Khanal, S. N., S. Anand, K. Muthukumarappan, and M. Huegli. 2014 Inactivation of thermoduric aerobic sporeformers in milk by ultrasonication. Food Contr. 37:232-239.

Kivelä, T. 1996. Easier cheese mould cleaning by ultrasonics. Scand. Dairy Inform. 10:34-35.

Korycka-Dahl, M., B. Ribadeau-Dumas, N. Chene, and J. Martal. 1983. Plasmin activity in milk. J. Dairy Sci. 66:704-711.

Lopez, P., F. J. Sala, J. L. de la Fuente, S. Condon, J. Raso, and J. Burgos. 1994. Inactivation of peroxidase, lipoxygenase and polyphenol oxidase by manothermosonication. J. Agric. Food Chem. $42: 252-256$.

Madadlou, A., M. E. Mousavi, Z. Emam-djomeh, M. Ehsani, and D. Sheehan. 2009. Sonodisruption of re-assembled casein micelles at different $\mathrm{pH}$ values. Ultrason. Sonochem. 16:644-648.

Makino, K., M. M. Mossoba, and P. Riesz. 1983. Chemical effects of ultrasound on aqueous solutions. Formation of hydroxyl radicals and hydrogen atoms. J. Phys. Chem. 87:1369-1377.

Manas, P., B. Munoz, D. Sanz, and S. Condon. 2006. Inactivation of lysozyme by ultrasonic waves under pressure at different temperatures. Enzyme Microb. Technol. 39:1177-1182.

Marshall, R. T., ed. 1992. Standard Methods for the Examination of Dairy Products. American Public Health Association, Washington, DC.

Metwalli, A. A. M., H. H. J. de Jongh, and M. A. J. S. van Boekel 1998. Heat inactivation of bovine plasmin. Int. Dairy J. 8:47-56.

Mulder, H., and P. Walstra. 1974. The Milk Fat Globule: Emulsion Science as Applied to Milk Products and Comparable Foods. Commonwealth Agricultural Bureaux, Farnham Royal, UK.

Newstead, D. F., G. Paterson, S. G. Anema, S. J. Coker, and A. R Wewala. 2006. Plasmin activity in direct-steam-injection UHTprocessed reconstituted milk: Effects of preheat treatment. Int. Dairy J. 16:573-579.

Nguyen, H. A. N., and S. G. Anema. 2010. Effect of ultrasonication on the properties of skim milk used in the formation of acid gels. Innov. Food Sci. Emerg. Technol. 11:616-622.

O'Sullivan, M. M., A. L. Kelly, and P. F. Fox. 2002. Influence of transglutaminase treatment on some physico-chemical properties of milk. J. Dairy Res. 69:433-442.

Patist, A., and D. Bates. 2008. Ultrasonic innovations in the food industry: From the laboratory to commercial production. Innov. Food Sci. Emerg. Technol. 9:147-154.

Pereda, J., V. Ferragut, J. M. Quevedo, B. Guamis, and A. J. Trujillo 2007. Effects of ultra-high pressure homogenization on microbial and physicochemical shelf life of milk. J. Dairy Sci. 90:1081-1093.

Pingret, D., G. Durand, A.-S. Fabiano-Tixier, A. Rockenbauer, C. Ginies, and F. Chemat. 2012. Degradation of edible oil during food processing by ultrasound: Electron paramagnetic resonance, physicochemical, and sensory appreciation. J. Agric. Food Chem. 60:7761-7768.

Politis, I., B. Zavizion, D. M. Barbano, and R. C. Gorewit. 1993. Enzymatic assay for the combined determination of plasmin plus plasminogen in milk: Revisited. J. Dairy Sci. 76:1260-1267.

Riener, J., F. Noci, D. A. Cronin, D. J. Morgan, and J. G. Lyng. 2009. Characterisation of volatile compounds generated in milk by highintensity ultrasound. Int. Dairy J. 19:269-272.

Riesz, P., and T. Kondo. 1992. Free radical formation induced by ultrasound and its biological implications. Free Radic. Biol. Med. $13: 247-270$.

Rollema, H. S., S. Visser, and J. K. Poll. 1983. Spectrophotometric assay of plasmin and plasminogen in bovine milk. Milchwissenschaft $38: 214-217$. 
Shanmugam, A., J. Chandrapala, and M. Ashokkumar. 2012. The effect of ultrasound on the physical and functional properties of skim milk. Innov. Food Sci. Emerg. Technol. 16:251-258.

Simon, M., and A. P. Hansen. 2001. Effects of various dairy packaging materials on the shelf life and flavor of pasteurized milk. J. Dairy Sci. 84:767-773.

Sorhaug, T., and L. Stepaniak. 1997. Psychrotrophs and their enzymes in milk and dairy products: Quality aspects. Trends Food Sci. Technol. 8:35-41.

Tiwari, B. K., C. P. O'Donnell, K. Muthukumarappan, and P. J. Cullen. 2009. Ascorbic acid degradation kinetics of sonicated orange juice during storage and comparison with thermally pasteurised juice. Lebenson. Wiss. Technol. 42:700-704

Toma, S., A. Gaplovsky, and J. L. Luche. 2001. The effect of ultrasound on photochemical reactions. Ultrason. Sonochem. 8:201-207.

van Boekel, M. A. J. S. 1998. Effect of heating on Maillard reactions in milk. Food Chem. 62:403-414.

Vercet, A., J. Burgos, and P. Lopez-Buesa. 2002. Manothermosonication of heat-resistant lipase and protease from Pseudomonas fluorescens: effect of $\mathrm{pH}$ and sonication parameters. J. Dairy Res. 69:243-254.

Villamiel, M., and P. de Jong. 2000a. Inactivation of Pseudomonas fluorescens and Streptococcus thermophilus in Trypticase soy broth and total bacteria in milk by continuous flow ultrasonic treatment and conventional heating. J. Food Eng. 45:171-179.

Villamiel, M., and P. de Jong. 2000b. Influence of high-intensity ultrasound and heat treatment in continuous flow on fat, proteins, and native enzymes of milk. J. Agric. Food Chem. 48:472-478.

Walstra, P., and R. Jenness. 1984. Rheological properties. Pages 290300 in Dairy Chemistry and Physics. John Wiley and Sons, New York, NY.

Wrigley, D. M., and N. G. Lorca. 1992. Decrease of Salmonella typhimurium in skim milk and egg by heat and ultrasonic wave treatment. J. Food Prot. 55:678-680.

Wu, H., J. G. Hulbert, and J. R. Mount. 2001. Effects of ultrasound on milk homogenization and fermentation with yogurt starter. Innov. Food Sci. Emerg. Technol. 1:211-218.

Zheng, L., and D. W. Sun. 2006. Innovative applications of power ultrasound during food freezing processes - A review. Trends Food Sci. Technol. 17:16-23.

Zisu, B., M. Schleyer, and J. Chandrapala. 2013. Application of ultrasound to reduce viscosity and control the rate of age thickening of concentrated skim milk. Int. Dairy J. 31:41-43. 